\section{Motivation and Retention of lowa Master Gardeners}

\author{
Bryn Takle ${ }^{1}$, Cynthia Haynes, and Denny Schrock
}

ADDITIONAL INDEX WORDS. social media, training methods, volunteer, gardening, horticulture, continuing education, altruism

SUMMARY. Recruitment and training of new volunteers is necessary to grow a Master Gardener organization, but retention of current individuals has advantages. Aligning reasons for volunteering with recruitment and continuing education topics with the interests of volunteers is essential in a successful recruitment and retention plan. The objectives of this study were to determine the motivations for volunteering in the Iowa Master Gardener program and to identify popular continuing education topics, preferred delivery methods, and social media usage among this audience. Learning about gardening and horticulture was the most important reason Iowa Master Gardeners volunteer with the program. In addition, altruism is important to these volunteers, but they do not recognize the full impact their projects have on their local community. They have a strong interest in learning about native plants and sustainable horticultural practices. The most preferred delivery methods were live presentations and workshops. Video presentations and webinars were generally less preferred. Respondents used certain social media sites, such as Facebook and Pinterest, some or a lot. Although this study was limited to Iowa Master Gardeners, results regarding motivation factors align closely with previous studies. We speculate that the results for advanced training topics, delivery methods, and social media usage would similarly align for Master Gardener programs across the country.

$\mathrm{T}$ he Master Gardener program was launched in Washington State in 1972 and has been established in all 50 states, Washington, DC, and several international locations. The program is based on three core concepts: helping local cooperative extension educators disseminate information, tailoring horticultural information to the local level, and providing quality information by working through land-grant universities (McAleer, 2005). Annually, over 82 million households in the United States participate in some type of home gardening activity (Matheny et al., 2009 ) creating continued high demand for dependable horticultural information.

The mission of the Iowa Master Gardener program is to provide current, research-based, home horticulture information and education to the citizens of Iowa through Iowa State University Extension and Outreach programs and projects. Since its inception in 1979 , more than 13,000 volunteers have been trained. The initial training involves a combination of face-to-face and web-based sessions in

Department of Horticulture, Iowa State University, 106 Horticulture Hall, Ames, IA 50011

${ }^{1}$ Corresponding author. E-mail: bryn@iastate.edu. a variety of topics related to horticulture. Annually, more than 300 individuals enroll in the training at more than 20 county extension offices throughout Iowa. In addition to training at county offices, participants spend a full day at the Iowa State University campus where groups rotate through a series of eight, hands-on workshops. Although no specific topics are required nationally for the core course training, similarities exist among programs (Moore and Bradley, 2015). In Iowa, the core topics include animal ecology, botany, composting, entomology, fruit culture, herbaceous ornamentals, houseplants, integrated pest management (IPM), sustainable home landscape design, pesticides and pesticide safety, plant pathology, plant propagation, soils and soil fertility, trees and shrubs, turfgrass management, vegetables and herbs, and weed science (Iowa State University Extension and Outreach, 2014).

In addition to at least $40 \mathrm{~h}$ of classroom instruction, interns must provide $40 \mathrm{~h}$ of community-based volunteer service to hone their skills. Upon completion of this requirement, interns are considered active Master Gardeners. To remain active, volunteers must acquire at least $10 \mathrm{~h}$ of continuing education and complete $20 \mathrm{~h}$ of volunteer service annually.

Recruitment and training of new volunteers is necessary to grow the organization, but retention of current individuals has advantages. Experienced Master Gardeners act as recruiters of new members and mentors to incoming interns (Stouse and Marr, 1992). Master Gardeners associate with the program for two main reasons: to increase horticultural knowledge and to help their community (Schrock et al., 2000b). Disappointment with the program and insufficient horticulture education have been cited as reasons for not continuing with the program (Meyer, 2004). Coordinating horticultural education with the interests of volunteers is important in increasing retention.

Social media is becoming another avenue for communication with volunteers. Current research shows that $81 \%$ of American adults use the Internet. Over half of those are using two or more social media sites (Duggan et al., 2015). Interaction through social media sites is a way for organizations to build relationships and engage volunteers (Waters et al., 2009).

The primary objective of this study was to determine the motivations for volunteering in the Iowa Master Gardener program. No baseline data exist on why volunteers choose to join the program. Secondary objectives were to identify popular continuing education topics, preferred delivery methods, and social media usage among Iowa Master Gardeners. Armed with this information, coordinators can tailor training to the interests of their program participants.

\section{Methodology}

Many survey tools exist for investigating the motivations of volunteers (Byrne and Caskey, 1985; Schmiesing et al., 2005; Wolford et al., 2001). One such instrument, the volunteer functions inventory (VFI), developed and tested by Clary et al. (1998) defined six motivational categories, or factors, to explain the rationale behind volunteering. These factors are career, enhancement, protective, social, understanding, and values.

The VFI was included in a larger survey administered to Iowa Master Gardeners. This instrument was developed 
in Qualtrics Survey Software (Qualtrics, Provo, UT) in Jan. 2015. Researchers and the research project were reviewed and determined exempt through Iowa State University's Institutional Review Board (IRB 14-492) before pilot testing and full survey distribution.

The pilot survey was sent on 2 Dec. 2014 to 31 Iowa Master Gardener county coordinators who were also active Iowa Master Gardener volunteers. Feedback was solicited regarding question design and overall usability, and based on this input, minor revisions were made to the instrument before full distribution.

One day before distribution of the full survey, an e-mail was sent to Iowa Master Gardeners describing the purpose of the survey, and explaining that participation would be voluntary and anonymous. This e-mail was delivered through Qualtrics, which was unfamiliar to many of the recipients. To confirm the legitimacy of the survey, an additional e-mail was sent directly from the researcher, the state coordinator, and the professor in charge of the Iowa Master Gardener program.

The distribution list was assembled from an online reporting system where Iowa Master Gardeners record volunteer service and continuing education hours. Counties that did not use this system provided e-mail addresses of their active Master Gardeners.

The full survey was distributed on 22 Jan. 2015. On 10 and 27 Feb. 2015 follow-up e-mails were sent via Qualtrics to potential participants who had not yet completed the survey. The survey closed on 23 Mar. 2015. Survey links were distributed to 3713 valid e-mail addresses. Of these, 1880 participants opened the e-mail and 1263 began or completed the survey. According to standards established by the American Association for Public Opinion Research, the response rate was $34.0 \%$ (AAPOR, 2008).

\section{Survey instrument development}

The survey of Iowa Master Gardeners consisted of a total of 49 questions, 11 of which were open-ended and 38 closed-ended. To address the first objective, two instruments were imbedded into the larger survey. The VFI uses responses to a set of 29 statements based on a 7 -point Likert scale (Likert, 1932), where 1 = " not at all important" and $7=$ "very important." From these responses, six motivational functional groups were identified: values, understanding, social, career, protective, and enhancement. A second set of questions consisted of 19 closed-ended statements. Rohs and Westerfield (1996) and Schrock et al. (2000a) used this instrument to address the distinction between personal gain and benefit to the individual's community. Minor modifications were made to the question set to improve clarity. These questions used a 5-point Likert scale, where 1 = "strongly disagree" and $5=$ "strongly agree." The results were reported as return on investment.

Questions addressing the second objective related to three distinct areas: topics for continuing education, delivery methods, and social media use. The 12 questions about topics for continuing education focused on regionally relevant horticultural subjects. These questions asked for responses based on a 4-point scale from "not at all interested" to "very interested." The eight questions pertaining to preferred delivery method for receiving training materials used the identical interest scale. The four questions regarding social media usage were based on a 4-point scale ranging from "not at all" to "a lot."

The data were analyzed using the SPSS software package (version 23.0; IBM, Armonk, NY). The data addressing volunteer motivation were classified using factor analysis. This statistical method creates latent variables, often called factors, which are not directly measurable but identify underlying similarities among responses (Field, 2009; Rummel, 1967). Principal axis factoring with varimax rotation was the extraction method used to identify the factors in this study. Cronbach's alpha was used to test for internal consistency within each question set. A Friedman test was used to determine significant differences in the remaining data. Post hoc testing using a Wilcoxon signed-rank test with a Bonferroni correction determined significant differences between ranked items.

\section{Results}

VOLUNTEER FUNCTIONS INVENTORY. This study found that six main factors described Master Gardeners' reasons for volunteering. The number of factors is the same as in studies by Clary et al. (1998) and Schrock et al. (2000b); however, some questions aligned differently. For this reason, the factors reported in Table 1 were renamed learning, altruism, society, self-esteem, relationship, and career to better reflect the realigned groupings. Learning factor statements relate to acquiring horticultural knowledge and skills. The altruism factor statements focus on helping others. Statements in the society factor relate to the importance of community to the participant. Self-esteem statements emphasize personal feelings and selfconfidence. The relationship factor involves statements pertaining to friends, and career factor statements relate to employment opportunities.

Cronbach's alpha showed strong internal reliability with a value of 0.930 for the VFI. Each factor was also measured with Cronbach's alpha, and all but one factor had values above 0.794 . The relationships group had an alpha value of 0.666 , which is likely low because only two statements aligned with this factor.

A significant difference was found between the means of the factors $\left(\chi^{2}=\right.$ $3054.89, P<0.001)$ using a Friedman test. A Wilcoxon signed-rank test with a Bonferroni correction determined every factor mean to be significantly different from each other $(P<0.008)$.

Learning was the most important reason Iowa Master Gardeners volunteer with the program. This agrees with previous work (Schrock et al., $2000 \mathrm{~b}$ ) and shows that Master Gardeners join the organization to learn more about horticulture and gardening. The statements "I can learn more about home gardening" and "Volunteering as a Master Gardener lets me learn horticulture through direct, hands-on experience" represented the top two mean scores (6.26 and 6.08, respectively). The six statements grouped into this factor collectively had the highest mean score of 5.48.

Altruism was the next most important reason Iowa Master Gardeners volunteer. The mean for this group (4.73) was lower than for learning, but significantly more important than all remaining factors. The highest rated statement in this group, "I feel it is important to help others," was the third highest mean statement (5.66).

Only three statements aligned in society. The statement means varied 
Table 1. Factor analysis means and statement groupings indicating motivations for volunteering with the Iowa Master Gardener program compared with the VFI.

\begin{tabular}{|c|c|c|}
\hline & Mean & VFI \\
\hline \multicolumn{3}{|l|}{ Learning $\left[1-7\right.$ scale $^{\mathrm{z}}\left(\right.$ group mean $\left.\left.=5.48 \mathrm{a}^{\mathrm{y}}\right)\right]$} \\
\hline I can learn more about horticulture and home gardening & 6.26 & $\mathrm{U}$ \\
\hline Volunteering as a Master Gardener lets me learn horticulture through direct, hands-on experience & 6.08 & $\mathrm{U}$ \\
\hline As a Master Gardener I can do something for a horticultural cause that is important to me & 5.49 & $\mathrm{C}$ \\
\hline Volunteering as a Master Gardener allows me to gain a new perspective on things & 5.22 & $\mathrm{U}$ \\
\hline Volunteering as a Master Gardener is a way to make new friends & 5.01 & $S$ \\
\hline Through the Master Gardener program I can explore my own strengths & 4.82 & $\mathrm{E}$ \\
\hline \multicolumn{3}{|l|}{ Altruism (group mean $=4.73 \mathrm{~b})$} \\
\hline I feel it is important to help others & 5.66 & V \\
\hline I am genuinely concerned about the home gardeners I am serving & 4.73 & V \\
\hline I feel compassion toward people in need & 4.62 & V \\
\hline I am concerned about those less fortunate than myself & 3.96 & $\mathrm{~V}$ \\
\hline \multicolumn{3}{|l|}{ Society $($ group mean $=4.33 \mathrm{c})$} \\
\hline People I know share an interest in community service & 4.65 & $S$ \\
\hline Others with whom I am close place a high value on community service & 4.18 & $S$ \\
\hline Volunteering is an important activity to the people I know best & 4.16 & $\mathrm{~V}$ \\
\hline \multicolumn{3}{|l|}{ Self-esteem $($ group mean $=3.20 \mathrm{~d})$} \\
\hline I can learn how to deal with a variety of people as a Master Gardener & 3.96 & $\mathrm{P}$ \\
\hline Volunteering as a Master Gardener increases my self-esteem & 3.92 & $\mathrm{E}$ \\
\hline No matter how bad I have been feeling, volunteering as a Master Gardener helps me to forget about it & 3.91 & $\mathrm{P}$ \\
\hline Volunteering as a Master Gardener makes me feel needed & 3.72 & $\mathrm{U}$ \\
\hline Volunteering as a Master Gardener helps me feel better about myself & 3.66 & $\mathrm{E}$ \\
\hline Volunteering as a Master Gardener makes me feel important & 3.34 & $\mathrm{E}$ \\
\hline By volunteering as a Master Gardener, I feel less lonely & 2.75 & $\mathrm{P}$ \\
\hline Volunteering as a Master Gardener is a good escape from my own troubles & 2.56 & S \\
\hline Volunteering as a Master Gardener helps me work through my own personal problems & 2.37 & $\mathrm{P}$ \\
\hline Doing Master Gardener volunteer work relieves me of some of the guilt over being more fortunate than others & 1.82 & $\mathrm{P}$ \\
\hline \multicolumn{3}{|l|}{ Relationships $($ group mean $=2.60 \mathrm{e})$} \\
\hline My friends volunteer as Master Gardeners & 2.78 & $S$ \\
\hline People I am close to want me to volunteer as a Master Gardener & 2.42 & $S$ \\
\hline \multicolumn{3}{|l|}{ Career $($ group mean $=1.84 \mathrm{f})$} \\
\hline The Master Gardener program allows me to explore different career options & 1.97 & $\mathrm{C}$ \\
\hline Through the Master Gardener program I can make new contacts that might help my business career & 1.89 & $\mathrm{C}$ \\
\hline Master Gardener volunteer experience will look good on my resume & 1.88 & $\mathrm{E}$ \\
\hline Volunteering as a Master Gardener can help me get my foot in the door at a place where I would like to work & 1.60 & $\mathrm{C}$ \\
\hline
\end{tabular}

$\mathrm{VFI}=$ volunteer functions inventory, $\mathrm{C}=$ career, $\mathrm{E}=$ enhancement, $\mathrm{P}=$ protective, $\mathrm{S}=$ social, $\mathrm{U}=$ understanding, $\mathrm{V}=$ values .

${ }^{\mathrm{z}}$ Likert scale responses: $\mathrm{l}=$ not at all important, $7=$ extremely important.

${ }^{y}$ Any two means not followed by the same letter are significantly different $(P<0.008)$ using Wilcoxon signed-rank test with Bonferroni correction.

from 4.65 to 4.16 with a group mean of 4.33. Self-esteem (3.20), relationship (2.60), and career (1.84) rated lower than other factors. Although career had the lowest mean score, it also had the largest SD.

Return ON INVESTMENT. Exploratory principal component analysis showed two strong factors (new discoveries and self) and two weak factors (community and recognition) affected respondents' perceived return on investment (Table 2). New discoveries included statements that relate to acquiring new knowledge, skills, or benefits. Self included statements about benefits to the individual and personal development. Community statements all had a strong society tie and recognition statements related to praise and prestige. Cronbach's alpha for this question set was 0.885 .

New discoveries and self had the strongest Cronbach's alpha scores, 0.787 and 0.853 , respectively. The community and recognition factors had much lower Cronbach's alpha values (0.636 and 0.404 , respectively), likely due to the limited number of statements that loaded in those factors.

Iowa Master Gardeners felt most strongly that the program allowed them to gain personal horticultural skills and knowledge. Six of the top seven statements involved these aspects and had mean scores greater than 4.0 on a 5 -point Likert scale. Participants of this study rated the statement "provides opportunity to learn about plants, soil, and horticultural topics" the highest. The statement "Many influential people in my community are Master Gardeners" with a mean of 2.95 was the lowest ranked by the participants.

New discoveries statements had the highest mean (4.30), followed by self statements at 3.86. A Friedman test found significant differences between the groups $\left(\chi^{2}=1243.98, P<\right.$ $0.001)$, and a Wilcoxon signed-rank test with a Bonferroni correction $(P<$ 0.013 ) found each group to be significantly different from one another.

Continuing EDUCATion. The data indicate that Iowa Master Gardeners have a strong interest in learning more about native plants (mean 3.41) and sustainable horticultural practices (mean 
3.24) as reported in Table 3 . A Friedman test showed a significant difference in interest among topics $\left(\chi^{2}=\right.$ 869.28, $P<0.001)$. Eighty-seven percent of respondents were moderately or very interested in more training and education about native plants. Many additional topics (landscape ecology, composting, plant propagation, plant diagnostics, and local foods) had means of 3.0 or above indicating at least moderate interest, but were of significantly less interest than the top two. Youth garden education (mean 2.56) and food safety (mean 2.56) were of least interest. Nearly half of the participants $(49.4 \%)$ recorded only slight or no interest in further training in youth garden education.

The demographic data were further analyzed by dividing the respondents by gender, age, and level of involvement (Table 4). Females preferred local foods and organic gardening significantly $(P<0.05)$ more than males, whereas males reported a higher mean preference score for
IPM. Dividing the group by age (less than 50 years, 50 or more years) showed that the younger group had a higher mean preference score $(P<$ $0.05)$ in four topics: sustainable horticultural practices, local foods, organic gardening, and composting. These topics were more preferred by the most active volunteers (those who reported greater than 40 volunteer hours during the previous year): youth garden education, IPM, plant diagnostics, and sustainable horticultural practices.

Table 2. Factor analysis means and statement groupings of Iowa Master Gardeners' perceived return on investment of their time and effort volunteering with the program.



${ }^{2}$ Likert scale responses: 1 = strongly disagree, $2=$ disagree, $3=$ neither agree nor disagree, $4=$ agree, $5=$ strongly agree.

yAny two means not followed by the same letter are significantly different $(P<0.013)$ using Wilcoxon signed-rank test with Bonferroni correction.

Table 3. Reported level of interest by survey respondents of proposed Iowa Master Gardener continuing education topics.

\begin{tabular}{|c|c|c|c|c|c|c|c|}
\hline Topic & $\mathbf{N}$ & $\begin{array}{c}\text { Not at all } \\
\text { interested (\%) }\end{array}$ & $\begin{array}{c}\text { Slightly } \\
\text { interested (\%) }\end{array}$ & $\begin{array}{c}\text { Moderately } \\
\text { interested (\%) }\end{array}$ & $\begin{array}{c}\text { Very } \\
\text { interested (\%) }\end{array}$ & Mean $^{\mathrm{z}}$ & SD \\
\hline Native plants & 961 & 2.1 & 10.9 & 30.5 & 56.5 & $3.41 \mathrm{a}^{\mathrm{y}}$ & 0.77 \\
\hline Landscape ecology & 955 & 3.8 & 16.6 & 40.7 & 38.8 & $3.15 \mathrm{c}$ & 0.83 \\
\hline Composting & 953 & 4.7 & 21.3 & 34.8 & 39.1 & $3.08 \mathrm{~cd}$ & 0.89 \\
\hline Plant propagation & 955 & 5.8 & 19.1 & 37.5 & 37.7 & $3.07 \mathrm{~cd}$ & 0.89 \\
\hline Organic gardening & 956 & 9.1 & 22.4 & 31.3 & 37.2 & $2.97 \mathrm{e}$ & 0.98 \\
\hline Integrated pest management & 952 & 8.6 & 25.2 & 38.9 & 27.3 & $2.85 \mathrm{f}$ & 0.92 \\
\hline Food safety & 952 & 13.3 & 30.9 & 33.5 & 22.3 & $2.65 \mathrm{~g}$ & 0.97 \\
\hline Youth garden education & 950 & 16.9 & 32.4 & 28.7 & 21.9 & $2.56 \mathrm{~g}$ & 1.01 \\
\hline
\end{tabular}

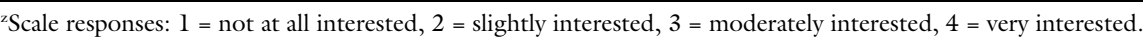

y Any two means not followed by the same letter are significantly different $(P<0.001)$ using Wilcoxon signed-rank test with Bonferroni correction. 
Delivery Methods. Live presentations and workshops were the most preferred form of training by Iowa Master Gardeners (Table 5). A Friedman test found a significant difference among preferred delivery methods $\left(\chi^{2}=1283.69, P<0.001\right)$. Post hoc testing with the Wilcoxon signed-rank test using a Bonferroni correction $(P=0.006)$ determined the top three preferred delivery methods to be significantly different from each other and all other methods.

More than $90 \%$ of participants were very $(68.6 \%)$ or moderately $(24.4 \%)$ interested in hands-on workshops. Similarly, more than $90 \%$ were very $(63.6 \%)$ or moderately $(29.7 \%)$ interested in face-to-face presentations or lectures. More than half (50.1\%) were very interested and almost onethird $(32.7 \%)$ were moderately interested in organized field trips. Means for video presentations and state electronic newsletters were not significantly different from each other. Similarly, means for self-paced online training modules and real-time Adobe Connect (Adobe Systems, San Jose, CA) webinars were not significantly different from each other. Although these methods were less preferred than the top three, more than two-thirds of respondents were moderately or very interested in these training methods. Almost half of respondents cited only slight $(29.4 \%)$ or no interest (19.2\%) in audio podcasts.

More in-depth analysis of the demographic data revealed several significant findings (all at $P<0.05$ ). Females more strongly preferred hands-on workshops and organized field trips compared with males (Table 6). State electronic newsletters, audio podcasts, real-time Adobe Connect webinars, and self-paced online training modules were more strongly preferred by 20- to 49-year-olds compared with those aged 50 years or older. Only face-to-face presentations/lectures were more strongly preferred by those aged 50 years or older. When sorted by level of involvement, those who were more involved had a greater preference for face-to-face presentations, real-time Adobe Connect webinars, hands-on workshops, and video presentations.

Social Media usage. Some social media sites were popular with Iowa Master Gardeners (Table 7) and a Friedman test indicated significant difference among them $\left(\chi^{2}=\right.$ 1284.23, $P<0.001)$. Facebook (Menlo Park, CA) was the most widely used, with almost $60 \%$ of respondents using the site some $(25.6 \%)$ or a lot $(34.2 \%)$. Pinterest (San Francisco, CA) ranked second, with more than a third $(33.6 \%)$ using it some (19.9\%) or a lot (13.7\%). Further investigation by gender revealed that females used both Facebook and Pinterest more than males. More than $75 \%$ of females used

Table 4. Iowa Master Gardeners' preferences for continuing education topics by gender, age group, and level of volunteer involvement.

\begin{tabular}{|c|c|c|c|c|c|c|c|c|c|c|c|c|c|c|c|}
\hline \multirow[b]{3}{*}{ Topic } & \multicolumn{5}{|c|}{ Gender } & \multicolumn{5}{|c|}{ Age $(y r)$} & \multicolumn{5}{|c|}{ Level of involvement (h) } \\
\hline & \multicolumn{2}{|c|}{ Female } & \multicolumn{2}{|c|}{ Male } & \multirow[b]{2}{*}{$\operatorname{Dif}^{y}$} & \multicolumn{2}{|c|}{$20-49$} & \multicolumn{2}{|c|}{$50+$} & \multirow[b]{2}{*}{ Dif } & \multicolumn{2}{|c|}{$0-40$} & \multicolumn{2}{|c|}{$>40$} & \multirow[b]{2}{*}{ Dif } \\
\hline & $\mathbf{N}$ & Mean $^{z}$ & $\mathbf{N}$ & Mean & & $\mathbf{N}$ & Mean & $\mathbf{N}$ & Mean & & $\mathbf{N}$ & Mean & $\mathbf{N}$ & Mean & \\
\hline $\begin{array}{l}\text { Sustainable horticultural } \\
\text { practices }\end{array}$ & 752 & 3.23 & 185 & 3.23 & 0.00 & 327 & 3.32 & 611 & 3.19 & $0.13^{x}$ & 459 & 3.18 & 388 & 3.33 & $-0.15^{x}$ \\
\hline Plant diagnostics & 747 & 3.03 & 182 & 3.16 & -0.13 & 324 & 3.12 & 606 & 3.01 & 0.11 & 455 & 2.97 & 386 & 3.13 & $-0.16^{\mathrm{x}}$ \\
\hline Composting & 752 & 3.10 & 184 & 3.01 & 0.09 & 327 & 3.19 & 610 & 3.02 & $0.17^{\mathrm{x}}$ & 458 & 3.05 & 389 & 3.08 & -0.03 \\
\hline Integrated pest management & 752 & 2.82 & 184 & 3.00 & $-0.18^{x}$ & 327 & 2.84 & 610 & 2.85 & -0.01 & 456 & 2.77 & 389 & 2.96 & $-0.19^{x}$ \\
\hline Organic gardening & 755 & 3.00 & 185 & 2.84 & $0.16^{x}$ & 328 & 3.12 & 613 & 2.88 & $0.24^{\mathrm{x}}$ & 460 & 2.92 & 389 & 3.01 & -0.09 \\
\hline Local foods & 752 & 3.03 & 184 & 2.84 & $0.19^{x}$ & 328 & 3.11 & 609 & 2.93 & $0.18^{x}$ & 458 & 2.98 & 389 & 3.02 & -0.04 \\
\hline Food safety & 752 & 2.64 & 184 & 2.66 & -0.02 & 328 & 2.64 & 609 & 2.64 & 0.00 & 458 & 2.61 & 389 & 2.69 & -0.08 \\
\hline
\end{tabular}

${ }^{2}$ Scale responses: 1 = not at all interested, 2 = slightly interested, $3=$ moderately interested, 4 = very interested.

${ }^{y}$ Dif $=$ the difference in means within each category (gender, age, and level of involvement).

x Statistically significant at $P<0.05$ using Wilcoxon signed-rank test with Bonferroni correction.

Table 5. Reported level of interest by survey respondents of various Iowa Master Gardener training delivery methods.

\begin{tabular}{|c|c|c|c|c|c|c|c|}
\hline Method & $\mathbf{N}$ & $\begin{array}{c}\text { Not at all } \\
\text { interested (\%) }\end{array}$ & $\begin{array}{c}\text { Slightly } \\
\text { interested (\%) }\end{array}$ & $\begin{array}{c}\text { Moderately } \\
\text { interested (\%) }\end{array}$ & $\begin{array}{c}\text { Very } \\
\text { interested (\%) }\end{array}$ & Mean $^{\mathrm{z}}$ & SD \\
\hline Hands-on workshops & 949 & 0.5 & 6.4 & 24.4 & 68.6 & $3.61 \mathrm{a}^{\mathrm{y}}$ & 0.63 \\
\hline Organized field trips & 944 & 2.8 & 14.4 & 32.7 & 50.1 & $3.30 \mathrm{c}$ & 0.82 \\
\hline Video presentations & 943 & 4.7 & 16.3 & 46.7 & 32.3 & $3.07 \mathrm{~d}$ & 0.82 \\
\hline State electronic newsletters & 941 & 5.3 & 18.1 & 42.4 & 34.2 & $3.06 \mathrm{~d}$ & 0.86 \\
\hline Audio podcasts & 928 & 19.2 & 29.4 & 34.3 & 17.1 & $2.49 \mathrm{f}$ & 0.99 \\
\hline
\end{tabular}

${ }^{2}$ Scale responses: 1 = not at all interested, 2 = slightly interested, $3=$ moderately interested, 4 = very interested.

yAny two means not followed by the same letter are significantly different $(P<0.006)$ using Wilcoxon signed-rank test with Bonferroni correction.

${ }^{x}$ Adobe Systems, San Jose, CA. 
Table 6. Iowa Master Gardeners' preferences for continuing education delivery methods by gender, age group, and level of volunteer involvement.

\begin{tabular}{|c|c|c|c|c|c|c|c|c|c|c|c|c|c|c|c|}
\hline \multirow[b]{3}{*}{ Method } & \multicolumn{5}{|c|}{ Gender } & \multicolumn{5}{|c|}{ Age (yr) } & \multicolumn{5}{|c|}{ Level of involvement (h) } \\
\hline & \multicolumn{2}{|c|}{ Female } & \multicolumn{2}{|c|}{ Male } & \multirow[b]{2}{*}{ Dif $^{y}$} & \multicolumn{2}{|c|}{$20-49$} & \multicolumn{2}{|c|}{$50+$} & \multirow[b]{2}{*}{ Dif } & \multicolumn{2}{|c|}{$0-40$} & \multicolumn{2}{|c|}{$>40$} & \multirow[b]{2}{*}{ Dif } \\
\hline & $\mathbf{N}$ & $\operatorname{Mean}^{z}$ & $\mathbf{N}$ & Mean & & $\mathbf{N}$ & Mean & $\mathbf{N}$ & Mean & & $\mathbf{N}$ & Mean & $\mathbf{N}$ & Mean & \\
\hline Face-to-face presentations & 754 & 3.57 & 182 & 3.50 & 0.07 & 327 & 3.49 & 609 & 3.59 & $-0.10^{\mathrm{x}}$ & 457 & 3.52 & 385 & 3.64 & $-0.12^{x}$ \\
\hline Organized field trips & 750 & 3.34 & 181 & 3.17 & $0.17^{x}$ & 327 & 3.31 & 605 & 3.30 & 0.01 & 457 & 3.28 & 382 & 3.36 & $-0.08^{x}$ \\
\hline Video presentations & 749 & 3.07 & 182 & 3.08 & -0.01 & 326 & 3.09 & 606 & 3.06 & 0.03 & 453 & 3.01 & 385 & 3.13 & $-0.12^{x}$ \\
\hline State electronic newsletters & 747 & 3.06 & 182 & 3.03 & 0.03 & 325 & 3.15 & 605 & 3.00 & $0.15^{\mathrm{x}}$ & 452 & 3.01 & 384 & 3.09 & -0.08 \\
\hline $\begin{array}{l}\text { Real-time Adobe } \\
\text { Connect webinars }\end{array}$ & 749 & 2.93 & 181 & 2.95 & -0.02 & 327 & 3.07 & 604 & 2.85 & $0.22^{\mathrm{x}}$ & 452 & 2.84 & 383 & 2.98 & $-0.14^{x}$ \\
\hline Audio podcasts & 741 & 2.49 & 176 & 2.52 & -0.03 & 321 & 2.67 & 596 & 2.39 & $0.28^{\mathrm{x}}$ & 448 & 2.44 & 379 & 2.53 & -0.09 \\
\hline
\end{tabular}

${ }^{\mathrm{z}}$ Scale responses: 1 = not at all interested, 2 = slightly interested, $3=$ moderately interested, 4 = very interested.

${ }^{y}$ Dif $=$ the difference in means within each category (gender, age, and level of involvement).

${ }^{x}$ Statistically significant at $P<0.05$ using Wilcoxon signed-rank test with Bonferroni correction.

wAdobe Systems, San Jose, CA.

Table 7. Reported level of usage of various social media sites by Iowa Master Gardeners.

\begin{tabular}{lccccccc}
\hline Social media site $^{\mathrm{z}}$ & $\mathbf{N}$ & None (\%) & Little (\%) & Some (\%) & A lot (\%) & Mean $^{\mathrm{y}}$ & SD \\
\hline Facebook & 950 & 26.5 & 13.7 & 25.6 & 34.2 & $2.67 \mathrm{a}^{\mathrm{x}}$ & 1.20 \\
Female & 755 & 24.9 & 11.8 & 26.4 & 37.0 & & \\
Male & 182 & 33.5 & 20.9 & 23.1 & 22.5 & & \\
Pinterest & 930 & 47.0 & 19.5 & 19.9 & 13.7 & $2.00 \mathrm{~b}$ & 1.10 \\
Female & 740 & 39.6 & 20.8 & 23.4 & 16.2 & & \\
Male & 178 & 77.0 & 14.0 & 5.6 & 3.4 & & \\
Twitter & 926 & 82.5 & 10.2 & 5.5 & 1.8 & $1.27 \mathrm{c}$ & 0.65 \\
Female & 733 & 82.3 & 10.4 & 5.7 & 1.6 & & \\
Male & 181 & 84.0 & 8.3 & 5.0 & 2.8 & & \\
Instagram & 923 & 87.1 & 6.5 & 4.2 & 2.2 & $1.21 \mathrm{c}$ & 0.62 \\
Female & 733 & 86.1 & 7.1 & 4.5 & 2.3 & & \\
Male & 179 & 91.6 & 3.4 & 3.4 & 1.7 & & \\
\hline
\end{tabular}

${ }^{\mathrm{z} F a c e b o o k}$ (Menlo Park, CA), Pinterest (San Francisco, CA), Twitter (San Francisco, CA), Instagram (San Francisco, CA).

'Scale responses: 1 = none, 2 = little, 3 = some, 4 = a lot.

xAny two means not followed by the same letter are significantly different $(P<0.013)$ using Wilcoxon signed-rank test with Bonferroni correction.

Facebook and $60.4 \%$ used Pinterest. Facebook use by males was $66.5 \%$ while only $33 \%$ of them used Pinterest. More than $80 \%$ of Iowa Master Gardeners did not use Twitter (San Francisco, CA) or Instagram (San Francisco, CA).

\section{Discussion}

Motivational FaCtors. Schrock et al. (2000b) found that Missouri Master Gardeners cited two of six factors in the VFI as reasons for volunteering. These were to obtain horticultural knowledge for personal use (understanding) and to help others (values). Similarly, Waliczek et al. (2002) showed that over $73 \%$ of Texas Master Gardeners surveyed hoped to gain horticultural knowledge, and 33\% joined with the intention of providing a benefit for the community.
Overall, the motivations of the Iowa Master Gardeners align closely to previous studies (Rohs and Westerfield, 1996; Schrock et al., 2000a). Learning more about horticulture and altruism were the two most important reasons they chose to volunteer with the program.

The six factors described by Clary et al. (1998) held true for the Missouri Master Gardener program (Schrock et al., 2000b) but several differences were seen in the current study. For example, this study found the statements "As a Master Gardener I can do something for a horticultural cause that is important to me" and "Through the Master Gardener program I can explore my own strengths" factored into new discoveries. In the previous studies, they factored into career and enhancement, respectively. This suggests that Iowa Master Gardeners considered these statements have a strong connection to learning, especially new horticultural skills.

The altruism factor aligned closely with previous work, only omitting the statement "Volunteering is an important activity to the people I know best." It appears the wording of this statement aligns more closely with other society statements, which is where it factored in this study.

The broad social category seen in previous studies showed a dichotomy in this study with some statements relating to community and others referencing "friends." Respondents regarded community or societal aspects higher than relationships with friends when indicating their reasons for volunteering.

The two factors from previous studies called protective and enhancement aligned into a single factor (selfesteem) in this study. Given their relation to personal feelings of self, it can be argued that they should align together in one category.

Statements relating to career differed only slightly from previous work. The addition of the statement "Master Gardener volunteer experience will look good on my resume" obviously aligns closely with career. Iowa Master Gardeners determined the statement "As a Master Gardener I can do something for a horticultural cause that is important to me" aligned more closely with learning rather than career. The low interest in using Master Gardener experiences as a career builder 
could be attributed to the age demographic. More than $60 \%$ of respondents were 60 years of age or older (data not reported) and, therefore, not likely to begin a new career.

The second set of questions confirms the reasons why Iowa Master Gardeners join the program and shows how volunteers recognize their impact. Respondents agreed most strongly that new discoveries were their most important reason for participating in the program. To a lesser extent, they also agreed that self and recognition were important motivational factors for participating. Even though community was the lowest ranked factor, respondents were more likely to agree than disagree that it was an important factor for volunteering. One possible explanation for the relatively low ranking is the difficulty volunteers have quantifying the impact they have through beautification projects and public programming. Extension personnel and coordinators could emphasize the worth of local Master Gardener projects. Master Gardener coordinators should target educational activities and volunteer experiences to the interests of the volunteers. Relating these activities and experiences back to community needs will meet the altruistic motivations of the group while increasing engagement and retention.

Training topics AND DELIVERY METHODs. The Iowa Master Gardener program has maintained a stable active roster of $\approx 2400$ members since 2009. Typically, 300 Master Gardener interns are trained each year while at the same time $\approx 300$ previously active Master Gardeners exit the program. Meyer (2004) stated that more than a quarter of Master Gardeners in the Minnesota program left due to dislike or disappointment with the program, or failure to acquire enough horticulture education. Haynes and Trexler (2003) found that organizations must be cognizant of the quality and scope of training programs to ensure that the training meets volunteers' needs. The perceived quality of training materials and educational activities are key to the organization's success.

Local coordinators should use these findings both to design volunteer projects and continuing education activities of interest to the broader group. For example, knowing that Master Gardeners are highly interested in learning about native plants and prefer hands-on workshops, scheduling a regional seed-collecting workshop at a local state park could draw strong attendance.

Analyzing topics by various demographic groups showed that younger Iowa Master Gardeners were interested in popular topics such as local foods and organic gardening. The younger generation also had a higher preference for technologybased delivery methods. This agrees with findings from Madden et al. (2013) who showed that $89 \%$ of 30 to 49 -year-olds use the Internet compared with $52 \%$ of those over 65 years of age. Since the younger audience was only one-third of the sampled participants, this suggests that these modes of delivery would be more preferred if the Master Gardener demographics were more evenly distributed by age.

Gender differences revealed a couple of interesting connections. Males preferred IPM whereas females showed higher preference for local foods and organic gardening. Bhatti and Church (2000) cite a 1997 study by the Mintel Group (London, UK) which showed that males have a stronger interest in maintenance aspects of gardening, whereas women showed a greater interest in cultivation including organic gardening.

As expected, Iowa Master Gardeners preferred personal interaction with presenters. The top three preferred methods of delivery involve personal connections. Females preferred workshops and field trips more than did males. Since the rankings were the same for all methods in both groups, this could indicate a higher preference for group activities by females. Volunteers who were more active reported a significantly higher preference for half of the topics provided. It could be argued that as these volunteers become more engaged in the program, they have a higher appreciation of continuing education.

Social media shows potential to reach the Master Gardener audience. According to a national survey of Internet users, Facebook was used by more than $47 \%$ of respondents 50 years of age or older (Duggan and Brenner, 2012). In Iowa, Facebook was used by more than $67 \%$ of Master Gardeners in the same age range.
Facebook should also be considered as a way to reach a younger age demographic. Nationally, 78.0\% of Internet users in the 18- to 49-year age range used Facebook whereas $86.0 \%$ of Iowa Master Gardeners ( $\mathrm{n}=$ 100 ) in the 20- to 49-year age range reported at least some use of the site (data not reported). Although survey respondents were not asked whether they used Facebook to gain horticultural knowledge, usage of the Iowa Master Gardener Facebook page has more than doubled from 2015 to 2016 (data not presented). Duggan and Brenner (2012) reported that 25\% of females used Pinterest, whereas $60.4 \%$ of female Iowa Master Gardeners were reported using the site. Data published by Guenthner and Swan (2011) in Idaho found no difference between gender and use of electronic technology, although they did not focus on the same social media sites as this study. Increasingly, adults use multiple social media sites. Duggan et al. (2015) reported an increase from $42 \%$ to $52 \%$ of adults using multiple social media sites between 2013 and 2014 .

Providing training and professional development to volunteer groups has been shown to help with retention (Hager and Brudney, 2004). Appropriate training programs can serve both as strong retention and recruitment tools (Fahey et al., 2002). Identifying the motivations and interests of the target audience is necessary for engagement and retention. This study provides guidance for Iowa Master Gardener coordinators in creating future programming, optimal delivery methods, and using social media to interact with volunteers. Coordinators in other states may use these finding as a general guide but should survey their volunteers to identify specific preferences. Depending on the demographics of the group, topics and delivery methods and extent of social media usage could vary.

\section{Literature cited}

American Association for Public Opinion Research (AAPOR). 2008. Standard definitions: Final dispositions of case codes and outcome rates for surveys. 5 th ed. AAPOR, Lenexa, KS.

Bhatti, M. and A. Church. 2000. 'I never promised you a rose garden': Gender, 
leisure and home-making. Leis. Stud. 19 (3):183-197.

Byrne, R.A. and F. Caskey. 1985. For love or money? J. Ext. 23(3):3FEAl. 14 Apr. 2016. <http://www.joe.org/joe/1985fall/ sal.php>.

Clary, E.G., M. Snyder, R.D. Ridge, J. Copeland, A.A. Stukas, J. Haugenand, and P. Meine. 1998. Understanding and assessing the motivations of volunteers: A functional approach. J. Pers. Soc. Psychol. 74(6):1516-1530.

Duggan, M. and J. Brenner. 2012. The demographics of social media users. Pew Res. Ctr., Washington, DC.

Duggan, M., N. Ellison, C. Lampe, A. Lenhart, and M. Madden. 2015. Social media update 2014. Pew Res. Ctr., Washington, DC.

Fahey, C., J. Walker, and A. Sleigh. 2002. Training can be a recruitment and retention tool for emergency service volunteers. Austral. J. Emerg. Mgt. 17(3):3-7.

Field, A. 2009. Discovering statistics using SPSS. 3rd ed. Sage Publ., Thousand Oaks, CA.

Guenthner, J.F. and B.G. Swan. 2011. Extension learners' use of electronic technology. J. Ext. 49(1):1FEA2. 14 Apr. 2016. <http://www.joe.org/joe/2011february/ a2.php>.

Hager, M.A. and J.L. Brudney. 2004. Volunteer management practices and retention of volunteers. Urban Inst., Washington, DC.
Haynes, C. and C.J. Trexler. 2003. The perceptions and needs of volunteers at a university-affiliated public garden. HortTechnology 13:552-556.

Iowa State University Extension and Outreach. 2014. Resource guide for Iowa Master Gardeners. Iowa State Univ., Ames, IA.

Likert, R. 1932. A technique for the measurement of attitudes. Arch. Psychol. 22(140): 1-55.

Madden, M., A. Lenhart, M. Duggan, S. Cortesi, and U. Gasser. 2013. Teens and technology 2013. Pew Internet Amer. Life Project, Washington, DC.

Matheny, A.L., J. Traunfeld, M.J. Raupp, and A.E. Brown. 2009. Gardeners and gardening trends in the United States. Outlooks Pest Mgt. 20(2):51-56.

McAleer, P. 2005. A national survey of Master Gardener volunteer programs. Coop. State Res., Educ., Ext. Serv./Natl. Inst. Food Agr., Washington, DC.

Meyer, M.H. 2004. Why Master Gardeners stop volunteering: Lack of time. HortTechnology 14:437-438.

Moore, K. and L.K. Bradley. 2015. A review of extension Master Gardener training manuals from around the United States. J. Ext. 53(1):1TOT1. 14 Apr. 2016. <http://www.joe.org/joe/2015february/ ttl.php>.

Rohs, F.R. and R.R. Westerfield. 1996. Factors influencing volunteering in the Master Gardener program. HortTechnology 6:281-285.

Rummel, R.J. 1967. Understanding factor analysis. J. Conflict Resolut. 11(4): 444-480.
Schmiesing, R., J. Soder, and S. Russell. 2005. What motivates volunteers to serve in a youth literacy program. J. Ext. 43 (6):6RIB4. 14 Apr. 2016. <http://www. joe.org/joe/2005december/rb4.php>.

Schrock, D.S., M. Meyer, P. Ascher, and M. Snyder. 2000a. Benefits and values of the Master Gardener program. J. Ext. 38 (1):1RIB2. 14 Apr. 2016. <http://www. joe.org/joe/2000february/rb2.php>.

Schrock, D.S., M. Meyer, P. Ascher, and M. Snyder. 2000b. Reasons for becoming involved as a Master Gardener. HortTechnology 10:626-630.

Stouse, L. and C. Marr. 1992. Retaining Master Gardener volunteers. HortTechnology 2:244-245.

Waliczek, T.M., R. Boyer, and J.M. Zajicek. 2002. The Master Gardener program: Do benefits of the program go beyond improving the horticultural knowledge of the participants? HortTechnology 12: 432-436.

Waters, R.D., E. Burnett, A. Lamm, and J. Lucas. 2009. Engaging stakeholders through social networking: How nonprofit organizations are using Facebook. Public Relat. Rev. 35(2):102-106.

Wolford, M., K. Cox, and K. Culp, III. 2001. Effective motivators for Master Volunteer program development. J. Ext. 39(2):2RIB4. 14 Apr. 2016. <http:// www.joe.org/joe/200lapril/rb4.php>. 